\title{
The Evaluation in Different Temperature of Acute Toxic Effect of Cadmium on Gammarus pulex (Freshwater Amphipoda)
}

\author{
Osman SERDAR ${ }^{1 *} \quad$ Rahmi AYDIN $^{2} \quad$ Metin ÇALTA $^{3}$ \\ 1* Munzur Üniversitesi Su Ürünleri Fakültesi, 62000 TUNCELİ. $\quad$ (D): https://orcid.org/0000-0003-1744-8883 \\ ${ }_{2}^{2}$ Munzur Üniversitesi Tunceli MYO, Bitkisel ve Hayvansal Üretim Bölümü, 62000 TUNCELİ. B: https://orcid.org/0000-0002-3002-0892

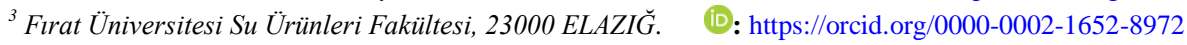

How to cite: Serdar, O., Aydın, R. \& Çalta, M. (2019). The evaluation in different temperature of acute toxic effect of cadmium on Gammarus pulex (Freshwater Amphipoda). Anatolian Env. and Anim. Sciences, 4(3), 366-370.

Atıf yapmak için: Serdar, O., Aydın, R. \& Çalta, M. (2019). Kadmiyumun Gammarus pulex (Tatlısu Amfipodu) üzerine akut toksik etkilerinin farklı sıcaklıklarda değerlendirilmesi. Anadolu Çev. ve Hay. Dergisi, 4(3), 366-370.

\begin{abstract}
In this study, the $\mathrm{LC}_{50}$ values of the cadmium (Cd) toxicity on the Gammarus pulex were investigated. In this study, it was aimed to determine the change of $\mathrm{LC}_{50}$ values of $\mathrm{Cd}$ at $G$. pulex at 10,14 and $18^{\circ} \mathrm{C}$. The lethal concentration ( $\left.\mathrm{LC}_{50}\right)$ values for $G$. pulex which were exposed to various $\mathrm{Cd}$ concentrations for 96 hours were determined at different temperatures as 10,14 and $18^{\circ} \mathrm{C}$. $\mathrm{LC}_{50}$ values obtained by probit analysis were found to be; $51.79 \pm 1.2 \mu \mathrm{g} \mathrm{L}^{-1}$ for $10^{\circ} \mathrm{C}, 47.67 \pm 0.6 \mu \mathrm{g} \mathrm{L}^{-1}$ for $14^{\circ} \mathrm{C}$ and $33.93 \pm 0.6 \mu \mathrm{g} \mathrm{L}-1$ for $18^{\circ} \mathrm{C}$. $\mathrm{LC}_{50}$ values were found to decrease due to the increase in temperature.
\end{abstract}

Keywords: Acute toxicity, cadmium, Gammarus pulex, temperature.

\section{Kadmiyumun Gammarus pulex (Tatlısu Amfipodu) Üzerine Akut Toksik Etkilerinin Farklı Sıcaklıklarda Değerlendirilmesi}

Öz: Bu çalışmada, Gammarus pulex üzerinde kadmiyum (Cd) toksisitesinin su sıcaklığına bağlı akut toksisite etkilerinden LC $\mathrm{L}_{50}$ değerleri araştırıldı. Yapılan bu çalışma ile Cd'un G. pulex'te 10,14 ve $18^{\circ} \mathrm{C}$ sicaklıklardaki $\mathrm{LC}_{50}$ değerleri değişiminin tespit edilmesi amaçlanmıştır. Çeşitli Cd konsantrasyonlarına 96 saat boyunca maruz kalan G. pulex için $\mathrm{LC}_{50}$ değerleri, 10,14 ve $18^{\circ} \mathrm{C}$ olarak farklı sıcaklıklarda belirlendi. Probit analizinden elde edilen $\mathrm{LC}_{50}$ değerleri; $10^{\circ} \mathrm{C}$ için, $51.79 \pm 1.2 \mu \mathrm{g} \mathrm{L}^{-1}, 14^{\circ} \mathrm{C}$ için $47.67 \pm 0.6 \mu \mathrm{g} \mathrm{L}{ }^{-1}$ ve $18^{\circ} \mathrm{C}$ için $33.93 \pm 0.6 \mu \mathrm{g} \mathrm{L}^{-1}$ olarak belirlenmiştir. LC 50 değerleri, sıcaklık arttıkça daha düşük konsantrasyonlarda belirlenmiştir. 


\section{INTRODUCTION}

Heavy metals, which have increased concentration in water environment due to the effects of both natural resources and anthropogenic factors, can be carried by aquatic organisms and increased to upper trophic levels through the food chain (Hilmy et al., 1985; Nemsock \& Hughes, 1988). While heavy metals cause mortality in high ambient concentrations, low ambient concentrations can cause various biochemical and physiological functions of aquatic organisms (Moraitou-Apostolopoulou and Verriopoulos, 1982; Heath, 1995).

Heavy metal pollution in aquatic ecosystems is one of the threats to ecosystem health and poses a great risk to aquatic organisms (Del Valls et al., 1998; Türkoğlu, 2008; Tokatll, 2012).

Cadmium (Cd), which is one of the heavy metals with toxic effect in environmental pollutants, is very harmful for aquatic organisms even at low concentrations (Katalay and Parlak, 2002; Asri et al., 2007). In addition, Cd is the heavy metal element with the highest solubility in water. Therefore, the diffusion rate is high.

$\mathrm{Cd}$, one of the heavy metals that have toxic effects in environmental pollutants, is very harmful to aquatic life even in low concentrations (Katalay \& Parlak, 2002; Asri et al., 2007). The water solubility of $\mathrm{Cd}$ is one of the highest heavy metals. Therefore, the rate of diffusion is high. It is also not one of the elements necessary for human life. Due to its solubility properties, $\mathrm{Cd}^{+2}$ is taken into biological systems by plant and aquatic organisms and has the property of accumulation (Duffus, 1980).

One of the biggest problems facing the world today is increasing global warming. In particular, the increase in global heat caused by the excessive use of fossil fuels affects the whole world. Greenhouse gases, pesticides, heavy metals, increase as a result of human activities and play a negative role in aquatic environments and aquatic organisms (Mol \& Doğruyol, 2012).

$\mathrm{LC}_{50}$, which is one of the acute toxicity tests, is expressed as the amount of the substance that kills $50 \%$ of the organisms in a given environment for a certain period time. These studies are usually carried out in $24,48,72$ and 96 hour periods (Çetinkaya, 2005).

Water pollution is known to have a direct effect on living organisms. For this reason, bioindicator species are used to determine the decrease in the environmental quality of water pollution (Kazanc1 et al., 1997). They are the aquatic organisms most affected by water pollution. The Gammarus, known to water indicators, are known to be sentive to many toxic substances. Therefore, it is use in toxicological studies is increasing Gammarus, known as clean water indicators, are knownto be sensitiveto many toxic substances. Therefore, it is use in toxicological studies is increasing (Demirsoy, 1998).
The aim of this study was to determine the acute toxic effect of $\mathrm{Cd}$ heavy metal which is widely used in today's industry, on G. pulex at different temperatures.

\section{MATERIAL and METHODS}

Chemicals: $\mathrm{CdCl}_{2}$ used in the experiments was purchased from Sigma-Aldrich Chemical.

Test organism: The Gammaridae family is one of the most important invertebrate groups found in clean water resources (Cold and Forbes, 2004). This family plays a major role in the nutrients of freshwater ecosystems and is an important nutrient for fish species in the world (Rosenfeldt et al., 2015). Species identification of the organisms used in the research was made by Prof. Dr. Serap SALER, a faculty member of the Fisheries Faculty of Firat University. G. pulex organisms they were collected with dip nets from side arms of Munzur River in Tunceli, Turkey. Before the experimental study, organisms were adapted in the stock aquarium for least 30 days in a climate-controlled indoor environment at $18 \pm$ $0.5^{\circ} \mathrm{C}$ and a 12:12 light: dark cycle. Throughout adapt time, individuals were fed on refuted willow leaves. The organisms were checked per $24 \mathrm{~h}$.

Acute toxicity $\left(\boldsymbol{L} \boldsymbol{C}_{50}\right)$ : For all experiments carried out in this study, G. pulex samples that have reached reproductive maturity from adapted organisms were selected as healthy ones. Care was taken to ensure that the selected samples were male individuals who had reached the maturity of the sex and completed the shell change (W:0.08 $\pm 0.001 \mathrm{~g}$, L: $1.03 \pm 02 \mathrm{~mm}$ ). Ten organisms individuals were used for all concentration groups and replications, including the control group. In this study was used static non-renewal tests (Weber, 1991). Ten organisms were exposed in $1 \mathrm{~L}$ glass vessels to concentrations of different $\mathrm{Cd}$ concentrations of 96 h. $\mathrm{LC}_{50}$ values at temperatures of 10,14 and $18{ }^{\circ} \mathrm{C}$ were determined for G. pulex specimens after interval determination tests. The organisms were not fed during the experiments. The organisms were checked daily and dead individuals were counted and removed. $\mathrm{LC}_{50}$ experiments were repeated three times for each temperature.

Experimental design: The $\mathrm{LC}_{50}$ value was determined experimentally for each of 10,14 and $18^{\circ} \mathrm{C}$. Interval determination was performed for each temperature. $\mathrm{Cd}$ concentrations of $\mu \mathrm{g}$ per liter were prepared for temperatures (Table 1).

Table 1. Concentration ranges used to determine $\mathrm{LC}_{50}$

\begin{tabular}{cccccccccc}
\hline Temperature & Control & \multicolumn{7}{c}{ Concentrations $\left(\mu \mathrm{g} \mathrm{L}^{-1}\right)$} \\
\hline $10^{\circ} \mathrm{C}$ & 0.0 & 40.0 & 42.5 & 45.0 & 47.5 & 50.0 & 52.5 & 55.0 \\
& & & & & & & & \\
$14^{\circ} \mathrm{C}$ & 0.0 & 37.5 & 40.0 & 42.5 & 45.0 & 47.5 & 50.0 & 52.5 \\
$18^{\circ} \mathrm{C}$ & 0.0 & 30.0 & 32.5 & 35.0 & 37.5 & 40.0 & 42.5 & 45.0
\end{tabular}


Statistical analysis: The obtained data were calculated by probit analysis in SPSS packet (ver. 24.0) program $(\mathrm{p}<0.05)$ and $\mathrm{LC}_{50}$ values were determined for 96 hours (Weber, 1991).

\section{RESULTS and DISCUSSION}

Gammarus species are used to develop models that can be used for risk assessment of varying chemical concentrations (Ashauer et al., 2007; Beketov \& Liess, 2008; Demirci, 2018).

When the effect of temperature on the acute toxicity of $\mathrm{Cd}$ is examined, the $\mathrm{LC}_{50}$ values of $\mathrm{Cd}$ at 10,14 and $18^{\circ} \mathrm{C}$ are shown in Table 1.

Mortality rates: In this study, the death rates of $\mathrm{Cd}$ concentrations were determined for 96 hours at $10^{\circ} \mathrm{C}$ (Figure 1). The average mortality rates in three replicated experiments were determined as $0 ., 13.3,33.3,43.3,53.3$, 63.3, 76.7 and 86.7, respectively, depending on the concentrations ( 0.0 (control), 45.0, 47.5, 50.0, 52.5, 55.0, 57.5 and $60.0 \mu \mathrm{g} \mathrm{L}-1 \mathrm{Cd})$.

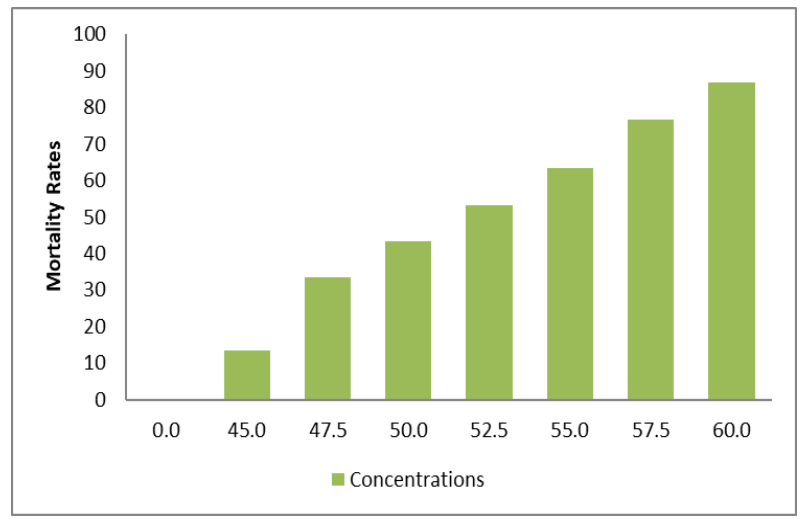

Figure 1. Mortality rates of G. pulex exposed to $\mathrm{Cd}$ at $10^{\circ} \mathrm{C}$ for 96 h.

In this study, the death rates of $\mathrm{Cd}$ concentrations were determined for 96 hours at $14^{\circ} \mathrm{C}$ (Figure 2). The average mortality rates in three replicated experiments were determined as $0 ., 10.0,23.3,36.7,53.3,56.7,73.3$ and 90.0, respectively, depending on the concentrations ( 0.0 (control), $40.0,42.5,45.0,47.5,50.0,52.5$ and $55.0 \mu \mathrm{g} \mathrm{L}-1$ Cd).

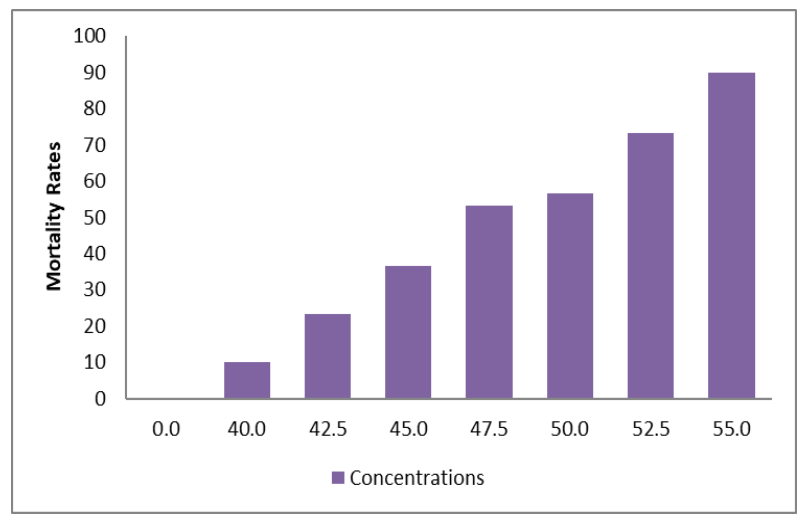

Figure 2. Mortality rates of G. pulex exposed to $\mathrm{Cd}$ at $14^{\circ} \mathrm{C}$ for 96 h.
In this study, the death rates of $\mathrm{Cd}$ concentrations were determined for 96 hours at $18^{\circ} \mathrm{C}$ (Figure 3). The average mortality rates in three replicated experiments were determined as $0 ., 13.3$, $33.3,46.7,56.7,70.0,76.7$ and 86.7 , respectively, depending on the concentrations (0.0 (control), 40.0, 42.5, 45.0, 47.5, 50.0, 52.5 and $\left.55.0 \mu \mathrm{g} \mathrm{L}{ }^{-1} \mathrm{Cd}\right)$.

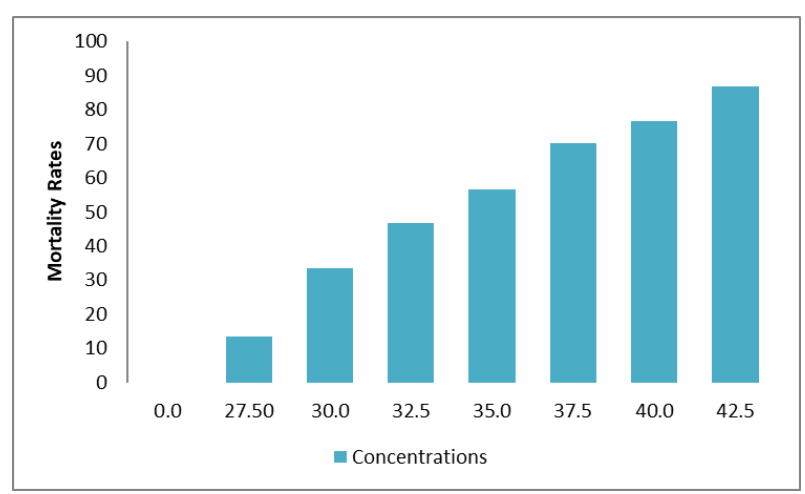

Figure 3. Mortality rates of G. pulex exposed to $\mathrm{Cd}$ at $18^{\circ} \mathrm{C}$ for 96 h.

Acute toxicity values: The $\mathrm{LC}_{50}$ value of the $\mathrm{Cd}$ at $10^{\circ} \mathrm{C}$ was found to be $51.79 \pm 1.2 \mu \mathrm{g} \mathrm{L}^{-1}$, the lower band value was 49.03 $\pm 1.3 \mu \mathrm{g} \mathrm{L}^{-1}$ and the upper band value was $54.43 \pm 1.3 \mu \mathrm{g} \mathrm{L}^{-1}$ (Figure $1)$.

The $\mathrm{LC}_{50}$ value of the $\mathrm{Cd}$ at $14^{\circ} \mathrm{C}$ was found to be $47.67 \pm$ $0.7 \mu \mathrm{g} \mathrm{L} \mathrm{L}^{-1}$, the lower band value was $45.27 \pm 0.7 \mu \mathrm{g} \mathrm{L}^{-1}$ and the upper band value was $50.10 \pm 0.7 \mu \mathrm{g} \mathrm{L}^{-1}$ (Figure 4).

The $\mathrm{LC}_{50}$ value of the $\mathrm{Cd}$ at $18^{\circ} \mathrm{C}$ was found to be $33.93 \pm$ $0.7 \mu \mathrm{g} \mathrm{L}^{-1}$, the lower band value was $31.39 \pm 0.8 \mu \mathrm{g} \mathrm{L}^{-1}$ and the upper band value was $37.00 \pm 0.8 \mu \mathrm{g} \mathrm{L}^{-1}$ (Table 2).

Table 2. $\mathrm{LC}_{50}$ values of $\mathrm{Cd}$ at temperatures of 10,14 and $18^{\circ} \mathrm{C}$ belonging to G. pulex individuals

\begin{tabular}{cccc}
\hline Temperature & $\begin{array}{c}\mathbf{L C}_{\mathbf{5 0}} \text { Value } \\
\left(\boldsymbol{\mu g} \mathbf{L}^{-1}\right)\end{array}$ & $\begin{array}{c}\text { Lower Band } \\
\left(\boldsymbol{\mu g} \mathbf{L}^{-\mathbf{1}}\right)\end{array}$ & $\begin{array}{c}\text { Upper Band } \\
\left(\boldsymbol{\mu g} \mathbf{~ L}^{-\mathbf{1}}\right)\end{array}$ \\
\hline $10^{\circ} \mathrm{C}$ & $51.79 \pm 1.2$ & $49.03 \pm 1.3$ & $54.43 \pm 1.3$ \\
$14^{\circ} \mathrm{C}$ & $47.67 \pm 0.7$ & $45.27 \pm 0.67$ & $50.10 \pm 0.7$ \\
$18^{\circ} \mathrm{C}$ & $33.93 \pm 0.7$ & $31.39 \pm 0.8$ & $37.00 \pm 0.8$ \\
\hline
\end{tabular}

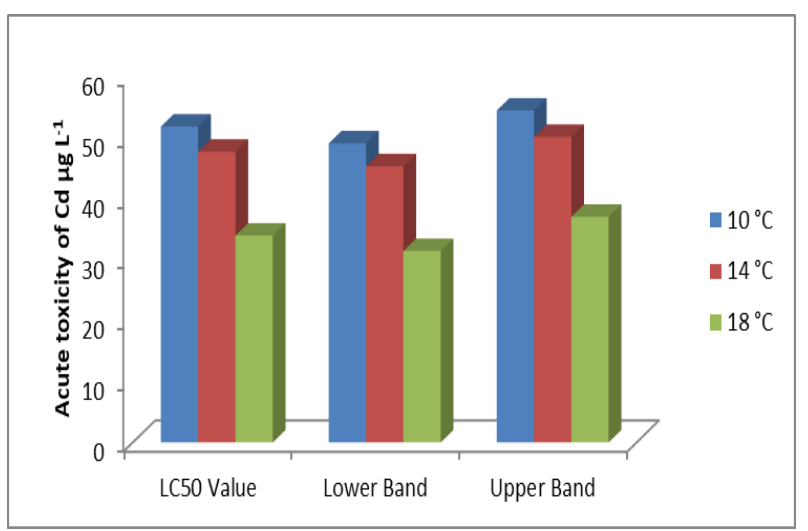

Figure 4. Temperature-dependent $\mathrm{LC}_{50}$ values of cadmium.

Toxicology examines the damage and destructive effects of physical or chemical agents on living organisms. In this context, aquatic toxicology tests aim to determine at 
what concentration any substance harms organisms on aquatic organisms (Karataş, 2005).

Bat et al., (2000) determined the $\mathrm{LC}_{50}$ values of zinc $(\mathrm{Zn})$, copper $(\mathrm{Cu})$ and lead $(\mathrm{Pb})$ toxicity in freshwater amphipods at $G$. pulex at three different temperatures $(15,20$ and $25^{\circ} \mathrm{C}$ ). They reported that $\mathrm{LC}_{50}$ values were decreased with temperature. Zauke, (1982) investigated the relationship between $\mathrm{Cd}$ 's acute toxicity to seasonal variation and environmental variables in Gammarus tigrinus natural populations and reported that there is a relationship between Cd concentration and water temperature. Piazza et al. (2016), conducted a study to evaluate the nature of the toxicity test in the study, in particular, the temperature and salinity changes in the presence of a toxic substance, and the environmental impact of information on the role of these parameters. Changes in temperature and salinity were observed separately, regardless of whether reference toxic substances were present, to obtain initial information the final test results. As a result, they reported that temperature and salinity were effective on organisms. Qiu \& Qian, (1999) were indicated that Amphitrite amphitrite at the larval stage is significantly affected by temperature, as well as markedly by both survival and development. Nasrolahi et al. 2013, showed that model organism low temperature and low salinity stress affects larval growth after 7 and 40 days and that these environmental changes can directly affect. In this study, the changes in the toxic effect of the calculated $\mathrm{Cd}$ were found to interact with the temperature increase (Figure 1). In this study, similar results were found in the previous literature.

\section{CONCLUSIONS}

Many factors that cause chemical pollution arising from various industrial activities, which accumulated in living organisms, can be transported in ecosystems from in the lowest of the food chain to in the top ring chain of the food chain (Demirci, 2013).

Physiological factors, such as temperature can be an important actor in ecotoxicological analyses when exposed to the stressors of organisms (Piazza et al., 2016).

In this study, it was determined that $\mathrm{Cd}$ heavy metal has a toxic effect to $G$. pulex aquatic indicator living individuals even at very low concentrations. The effect of $\mathrm{Cd}$ on organisms increased with the increase in temperature. With this study, it is estimated that global warming, which is one of the environmental problems of today, will affect all aquatic and hence land life.

\section{ACKNOWLEDGEMENTS}

This study was supported by the Scientific Research Project Coordination Unit of Munzur University under project number DRTUB015-01. We thank Prof. Dr. Serap SALER, because of the test organism species diagnosis.

\section{REFERENCES}

Ashauer, R., Boxall, A.B. \& Brown, C.D. (2007). New ecotoxicological model to simulate survival of aquatic invertebrates after exposure to fluctuating and sequential pulses of pesticides. Environmental Science \& Technology, 41, 1480-1486.

Asri, F.Ö., Sönmez, S. \& Çitak, S. (2007). Kadmiyumun çevre ve insan sağlığı üzerine etkileri. Derim, 24(1), 32-39.

Bat, L., Akbulut, M., Çulha, M., Gündoğdu, A. \& Satılmış, H.H. (2000). Effect of temperature on the toxicity of zinc, copper and lead to the freshwater amphipod Gammarus pulex pulex (L., 1758). Turkish Journal of Zoology, 24(4), 409-416.

Beketov, M.A. \& Liess, M. (2008). Acute and delayed effects of the neonicotinoid insecticide thiacloprid on seven freshwater arthropods. Environmental Toxicology and Chemistry: An International Journal, 27(2), 461-470.

Cold, A. \& Forbes, V.E., (2004). Consequences of a short pulse of pesticide exposure for survival and reproduction of Gammarus pulex. Aquatic Toxicology, 67(3), 287-299.

Çetinkaya, O. (2005). Akuatik toksikoloji: Karataş, M.(Ed), Balıkbiyodeneyleri. balık biyolojisi araştırma yöntemleri. No: 4, Bölüm: 7, 169-218s, Nobel Yayınevi, Ankara, Türkiye.

Del Valls, T.A., Blasco, J., Sarasquete, M.C., Forja, J.M. \& Gómez-Parra, A., (1998). Evaluation of Heavy Metal Sediment toxicity in littoral ecosystems using juveniles of the fish Sparus aurata. Ecotoxicology and environmental safety, 41(2), 157-167.

Demirci, Ö. (2013). Çeşitli pestisitlerin Gammarus kischineffensis'in antioksidan enzim sistemi ve bazl biyobelirteçler üzerine etkisi, (Doktora tezi). Dicle Üniversitesi Fen Bilimleri Enstitüsü Diyarbakır, Türkiye, 152s.

Demirci, Ö. (2018). İmidakloprit ve asetamiprit'in Gammarus kischineffensis (Amphipoda: Crustacea) üzerine akut toksik etkisinin değerlendirilmesi. I $\breve{g} d ı r$ Üniversitesi Fen Bilimleri Enstitüsü Dergisi, 8(3), 85-92.

Demirsoy, A. (1998). Yaşamın Temel Kuralları, omurgasızlar invertebrate (böcekler dışında), Cilt IKisım I, İkinci baskı.

Duffus, J.H. (1980). Environmental toxicology, Edward Arnold (Publishers) Ltd.164p.

Heath, A.G. (1995). Water Pollution and Fish Physiology. CRC Press Inc., Florida, 359p.

Hilmy, A.M., Shabana, M.B. \& Daabees, A.Y. (1985). Bioaccumulation of cadmium: toxicity in Mugil cephalus. Comparative biochemistry and physiology. C, Comparative pharmacology and toxicology, 81(1), 139-144. 
Karataş, M. (2005). Balık biyolojisi araştırma yöntemleri / Fish biology research methods. Nobel Yayınlar1 (772), 498.

Katalay, S. \& Parlak, H. (2002). Su kirliliğinin, Gobius niger Linn., 1758 (Pisces: Gobiidae)'in kan parametreleri üzerine etkileri. E. Ü. Su Ürünleri Dergisi, 19(1-2), 115-121.

Kazancı, N., Girgin, S., Dügel, M. \& Oğuzkurt, D. (1997). Akarsuların çevre kalitesi yönünden değerlendirilmesinde ve izlenmesinde biyotik indeks yöntemi. İmaj Yayıncılık, Ankara, $100 \mathrm{~s}$.

Mol, S. \& Doğruyol, H. (2012). İklim değişikliğinin su ürünlerine ve tüketimine etkisi. Journal of Fisheries Sciences, 6(4), 341-356.

Moraitou-Apostolopoulou, M. \& Verriopoulos, G. (1982). Individual and combined toxicity of three heavy metals; $\mathrm{Cu}, \mathrm{Cd}$, and $\mathrm{Cr}$ for the marine copepod Tisbe holothuriae. Hydrobiologia, 87, 83-87.

Nasrolahi, A., Pansch, C., Lenz, M. \& Wahl, M. (2013). Temperature and salinity interactively impact early juvenile development: a bottleneck in barnacle ontogeny. Marine Biology, 160, 1109-1117.

Nemsock, J.G., Hughes G.M., (1988). The effect of copper sulphate on some biochemical parameters of rainbow trout. Environmental Pollution, 49, 77-85.

Piazza, V., Gambardella, C., Canepa, S., Costa, E., Faimali, M. \& Garaventa, F. (2016). Temperature and salinity effects on cadmium toxicity on lethal and sublethal responses of Amphibalanus amphitrite nauplii. Ecotoxicology and environmental safety, 123, 8-17.

Rosenfeldt, R.R., Seitz, F., Zubrod, J.P., Feckler, A., Merkel, T., Lüderwald, S. \& Bundschuh, M. (2015). Does the presence of titanium dioxide nanoparticles reduce copper toxicity? A factorial approach with the benthic amphipod Gammarus fossarum. Aquatic Toxicology, 165, 154-159.
Tokatlı, C. (2012). Emet Çayı su, sediment ve bazı balık türlerinde ă̆ır metal birikimlerinin araştırılması, (Doktora tezi). Dumlupınar Üniversitesi Fen Bilimleri Enstitüsü, Kütahya, Türkiye, 227s.

Türkoğlu, M. (2008). Van Gölünden alınan su, sediment ve Inci Kefali (Chalcalburnus tarichi, Pallas, 1811) örneklerinde bazl ăgır metal düzeylerinin araştırılması, (Yüksek lisans tezi). Yüzüncü Yıl Üniversitesi, Fen Bilimleri Enstitüsü, Su Ürünleri Anabilim Dalı, Van, Türkiye 59s.

Qiu, J.W. \& Qian, P.Y. (1999). Tolerance of the barnacle Balanus amphitrite amphitrite to salinity and temperature stress: effects of previous experience. Marine Ecology Progress Series, 188, 123-132.

Weber, C.I. (Ed.). (1991). Methods for measuring the acute toxicity of effluents and receiving waters to freshwater and marine organisms. Cincinnati, Ohio: Environmental Monitoring Systems Laboratory, Office of Research and Development, US Environmental Protection Agency, P197.

Zauke, G.P. (1982). Cadmium in Gammaridae (Amphipoda: Crustacea) of the rivers Werra and Weser-II: Seasonal variation and correlation to temperature and other environmental variables. Water Research, 16(6), 785-792.

*Corresponding author's:

Osman SERDAR

Munzur Üniversitesi Su Ürünleri Fakültesi, 62000 Tunceli, Turkey.

E-mail : oserdar@munzur.edu.tr

ORCID : https://orcid.org/0000-0003-1744-8883

GSM : +90(505) 6959334 